\title{
Integration of Monetary and Fiscal Policy of the Countries of the Visegrad Group ${ }^{1}$
}

\author{
Stanislav Kappel ${ }^{2}$, Jan Jankỉ ${ }^{3}$
}

\begin{abstract}
The aim of this paper is to evaluate mutual interaction of monetary and fiscal policies in the countries of the Visegrad group, i.e. in the Czech Republic, Slovakia, Poland and Hungary. The relationship of monetary and fiscal policy - their coordination, cooperation or mutual antagonism - are basic determinants of successful implementation for economic policy of the state. Fiscal and monetary policies usually have different aims, and some conflict situations may arise in practical economic and political decision-making. Each policy has to make its decision with regard to the other one. Methodical approaches of this contribution are based on the game theory, which deals with the analysis of a wide range of decision situations with more participants (players) and it is primarily focused on the conflict situations. This game-theoretical approach is responsible for creating the theoretical model which is then dealt with in the empirical analysis. We find a distinctly stabilizing role of monetary policy and relatively problematic stabilizing role of fiscal policy in the analyzed countries. The dominant role of monetary policy is statistically confirmed in the case of the Czech Republic and Hungary.
\end{abstract}

Key words: Fiscal Policy, Interactions, Monetary Policy, Policy Coordination, Policy Objectives.

JEL Classification: E52, E58, E61 E62, E63.

\section{Introduction}

Monetary and fiscal policies belong among the principal economy policies and both of them have a certain degree of independence. Monetary policy (represented by a central bank in most countries) has gained independence on the government during last two decades. The main goals of these two policies, fiscal and monetary, are usually different. The primary objective of monetary policy is to maintain price stability (exceptions are possible), whereas fiscal policy is focused on high economic growth and the low rate of unemployment, or at the high rate of employment, alternatively.

\footnotetext{
${ }^{1}$ The contribution was made thanks to the project SGS SP2013/179 "The Interaction Monetary and Fiscal Policy in the Context of the Theory Game in the Countries of Visegrad Group“.

${ }^{2}$ VŠB - Technical University of Ostrava, Department of National Economy, Faculty of Economy, Sokolská třída 33, 70100 Ostrava, Czech Republic. Email: stanislav.kappel@vsb.cz.

${ }^{3}$ VŠ̉ - Technical University of Ostrava, Department of National Economy, Faculty of Economy, Sokolská třída 33, 70100 Ostrava, Czech Republic. Email: jan.janku@ vsb.cz.
} 
On the other hand, it is important to mention that achieving the goals of both policies does not happen in an inert environment. Both of them have to consider other macroeconomic indicators, impacts of their decisions and the behaviour of the other economicpolicy authorities. Then some different situations and scenarios can happen. The game theory is one of the methods how to study such situations. This approach contributes to the creation of a model. The core of this analysis is the research of reaction functions of monetary and fiscal authorities and their mutual influence.

The aim of this article is to evaluate the mutual interaction of monetary and fiscal policy in the countries of the Visegrad Group and decide which variables influence decisions of the monetary and fiscal policy.

A multivariate regression analysis is used to achieve this aim, and it is also the tool through which the dependence of the main instruments of both policies (it is a change of the primary balance as the percentage of GDP in the case of fiscal policy and the change of interest rates for monetary policy) on selected independent variables is examined. The surveyed states are the countries of the Visegrad Group, i.e. the Czech Republic, Slovakia, Poland and Hungary. The time period under observation starts with the first quarter 2000 and ends in the fourth quarter 2012.

\section{Theoretical and Empirical Basis}

The research of mutual influence of monetary and fiscal policy started after the World War II, especially in the articles of Friedman (1948) and Tinbergen (1954) who examined impacts of behaviour of monetary and fiscal policy separately.

In the sixties, Mundell (1962) argued in his model of the principle of the effective market classification that monetary policy ought to be aimed at external objectives and fiscal policy at internal objectives. It is assumed that fiscal and monetary policy can be used as independent instruments to achieve the two objectives ${ }^{4}$.

The development of mutual interactions of fiscal and monetary policy began in the 1980s, above all in the article of Sargent and Wallace (1981) called Some Unpleasant Monetarist Arithmetic. The authors mention opinions of monetarists, for example Friedman (1968), who had argued that a central bank cannot permanently influence the rate of the real output or unemployment. However, a central bank is able to control inflation, primarily during a long run, and so Sargent and Wallace (1981) point a situation (by monetary preconditions as well) when the central bank does not have the inflation under its control. The so called weak form of fiscal theory of the price level (FTPL) claims that although inflation has a monetary character, Friedman's money rule does not have to be true in all cases. Provided that fiscal policy is dominant and produces deficit budgets, monetary policy has to adapt by increasing monetary supply in the present days or in the future (fulfilment of inter-time budget restriction). There is no fundamental difference between debt monetization and debt financing because debt monetization

\footnotetext{
${ }^{4}$ An empirical estimate is for example in Mandel and Tomšík (2001) for the Czech Republic.
} 
means current increase of the price level and debt financing brings a future increase of a price level. According to Sargent and Wallace (1981), fiscal policy (in the case of its dominance) can make it impossible for monetary policy to have a price level under control.

For example Leeper (2010), Dixit and Lambertini (2003), Muscatelli (2002) or Nordhaus (1994) are among other authors who analyze mutual interaction between fiscal and monetary policy. Balboni, Buti and Larch (2007), Onorante (2006), Buti, Roeger and Velt (2001) or Melitz (2000) analyze the interaction of monetary and fiscal policy within a monetary union.

Buti, Roeger and Velt (2001) claim in their paper that a potential conflict between fiscal and monetary policy arises due to the fact that the objective function of a central bank (a bearer of monetary policy) is different from the objective function of a government (a representative of fiscal policy). The government tries to achieve stabilization or maximization of the output, whereas a central bank is maintaining price stability. Demertzis, Hughes Hallet and Viegi (2004), too, mention that a conflict arises due to the different goals of both policies and their mutual independence. The conflict is possible to analyze by the game theory. The mutual position of the both policies is an important question, too. Dixit and Lambertini (2003) consider Stackelberg's type of interaction when the decision is not simultaneous (the Nash's balance is reached ${ }^{5}$ ) but sequential (Stackleberg's balance). In that case, a central bank is a dominant player, makes the first step (it is spoken about Stackleberg's leader in the Game Theory) and fiscal policy follows it. A leader foresees the follower's reaction and this influences its policy. The follower has to adapt to the leader's policy. Balboni, Buti, Larch (2007) express it in a similar way. An opposite opinion is claimed by Beetsma a Bovenberg (1998), who deem that by different timing and decision-making of both policies, fiscal policy can become the Stackelberg's leader.

Melitz (2000) deals with empirical research of the interaction between monetary and fiscal policy. He studied $19 \mathrm{EU}$ and OECD countries by using the annual data from 1959 to 1995 . According to his results, fiscal policy reacts to stabilizing. With increasing a public debt, fiscal policy increases tax income and decreases state expenditure. Then, fiscal policy has a stabilizing effect in the economic cycle, but only at the revenue side of a budget (tax income). The expenditure side of the budget affects the economy cycle in a destabilizing way. The fact that monetary and fiscal policy are in a conflict is the latest significant finding of Melitz's contribution. Expansive fiscal policy leads to

\footnotetext{
${ }^{5}$ The Nash's balance is based on the assumption that players minimalize their loss functions in the same time without respect to the effects of economy-political arrangements of an opponent. Behavior of every player is determined from the beginning. It does not depend on the opponent's behavior. In the case of Nash's equilibrium, none of the players can improve its situation by a one-sided change of chosen strategy. The interaction of the Stackelberg's type, where the leader is one of the players, is one of the alternatives of this type of reaching and equilibrium which is often mentioned in literature. The leader's goal is to foresee reactions of the opponent, the follower, and to integrate this reaction into its own decision-making.
} 
restrictive monetary policy and vice versa: Expansive monetary policy results in restrictive fiscal policy. Unlike Melitz (2000), another author who looked into empirical research of the interaction, Wyplosz (1999), makes the estimation of reactive functions of monetary and fiscal policy individually, separately (Melitz estimated the equations of monetary policy simultaneously). Short-term interest rate is an instrument of monetary policy, and primary budget balance (in our contribution similarly) is an instrument of fiscal policy. He concludes that monetary authority works in line with the economic theory. As the rate of inflation increases, central bank increases the interest rate; when output gap lowers, central bank decreases the interest rates. Fiscal policy works in line of this theory as well. It reacts in a stabilizing way to the output gap and partly to the rate of inflation, too. His other conclusion is that monetary policy does not react to fiscal policy. On the other hand, certain statistically significant reactions of fiscal policy to monetary policy were found.

Řežábek (2011) is one of the Czech authors who deal with this problem. He researches mutual impact of monetary and fiscal policy by a different estimation of a potential product (the output gaps of both policies) through simultaneous equations estimation.

\section{Methodology and Data Description}

\section{The Game Theory}

The game theory is one of the methods to research the interaction between fiscal and monetary policies. In the frame of the game theory, an antagonistic and a nonantagonistic conflict can be distinguished. In analysis of the interaction of fiscal and monetary policy, it can be expected (with regard to the literature mentioned above) that this interaction (conflict) is non-antagonistic because the aims of fiscal and monetary policy are not necessarily in a contradiction. It should also be noted that a cooperative and a non-cooperative game can be distinguished in the non-antagonistic conflict. For the purposes of this paper, a non-cooperative game is preferable and a loss function of monetary and fiscal policy should be different and separate. In their contribution, Buti, Roeger and Veld (2001) show that a situation is generally expected in the available literature when the objective function of a central bank differs from the objective function of the government (a central bank aims to stabilize inflation through interest rates, while fiscal authority aims to stabilize the budget through fiscal deficit). The solution of the game-theoretical cooperative equilibrium would imply a common (loss, objective) function of the central bank and the fiscal authority (and both economic policy authorities would be thus focused on both stabilizing inflation rate and stabilizing the output). The studies mentioned above, especially empirical studies, have similar assumptions. More specifically, this problem is also expressed by Řežábek (2011), who shows that in the Czech Republic, we can only consider a non-cooperative equilibrium in the game theory. According to Řežábek (2011), in practice it is assumed that a central bank and a fiscal authority do not cooperate to set their economic policy instruments at the time of their decision. He emphasizes that this corresponds to his experience with economic policy in the Czech Republic and with a valid legislation which ensures the independence of a central bank and the government. The situation is similar in the other Visegrad countries. 
In the interaction of both policies and with the aforementioned assumptions, two basic situations would arise: coordination or conflict. In the case of coordination, both of these policies operate in the same direction. By expansionary policy - central bank reduces interest rates and government stimulates an aggregate demand and economic growth by using budget deficit. By restriction, monetary policy increases interest rate and fiscal policy reduces budget deficit or generates budget surplus. In a conflict, both of these policies operate in contradiction with one another. One of these policies pursues an expansion and the other one pursues a restriction. Two situations could arise again. In the first case, fiscal policy makes an expansion - stimulates aggregate demand through a fiscal stimulus to support the economic growth and reduce the unemployment, or, increases the employment (for example, when the economy is below its potential output or before elections). On the contrary, monetary policy makes restriction - increases the interest rates (for example when it faces inflationary pressures). In the second case, the situation is opposite. Fiscal policy makes restrictions - reduces deficits or produces budget surplus. On the contrary, a central bank performs an expansion - reduces interest rates (for example to face the deflationary pressures).

\section{Empirical model}

Thus, we can analyze how both policies are dependent on the business cycle, how authorities behave during fulfilment of their objective function and the extent of reaction to each other. The formulation of the functions is based on the articles by Wyplosz (1999), Melitz (2000) and Řežábek (2011), and it takes inspiration from these articles in creation of reaction functions of both economic political authorities. Generally, we can describe the dependent variables of both authorities as a change of the main policy instrument. The independent variables include a matrix of changing lagged values of the selected variables, a matrix of actual situation of the selected variables and the change of the other policy.

The model for fiscal policy has the following specification:

$$
\Delta\left(\frac{P}{Y}\right)_{t}=\alpha_{0}+\alpha_{1} \Delta d_{t-1}+\alpha_{2} E y_{t}+\alpha_{3}\left(\frac{P}{Y}\right)_{t-1}+\alpha_{4} u_{t}+\alpha_{5} \Delta i_{t}+\varepsilon_{t},
$$

where $\Delta\left(\frac{P}{Y}\right)_{t}$ is the change of the primary balance as the percentage of GDP between the period $t$ and the period $t-1$. This variable represents fiscal policy. $\Delta d_{t-1}$ is the change of the government debt in the absolute value lagged by one period. $E y_{t}$ is the output gap of GDP at the time $t,\left(\frac{P}{Y}\right)_{t-1}$ is the value of primary balance to the percentage of GDP lagged by one period, $u_{t}$ is the rate of unemployment in $\%$ at time $t, \Delta i_{t}$ is the change of the interest rate of the central bank between period $t$ and period $t-1$. This variable represents monetary policy.

The model for monetary policy has the following specification:

$$
\Delta i_{t}=\beta_{0}+\beta_{1} \Delta i_{t}^{G B}+\beta_{2} E y_{t}+\beta_{3} \Delta \pi_{t}+\beta_{4} \Delta R E E R_{t}+\beta_{5} \Delta\left(\frac{P}{Y}\right)_{t}+\epsilon_{t} .
$$

The variable $\Delta i_{t}$ represents monetary policy and its change of an interest rate of the central bank between period $t$ and period $t-1 . \Delta i_{t}^{G B}$ is the change of the interest rate of ten-year government bond yield between period $t$ and $t-1$ (it represents long term interest rates), $E y_{t}$ is the output gap of GDP in the period $t, \Delta \pi_{t}$ is the change of the 
rate of inflation between period $t$ and period $t-1, \triangle R E E R_{t}$ is the change of real effective exchange rate between period $t$ and period $t-1 . \Delta\left(\frac{P}{Y}\right)_{t}$ represents fiscal policy and it is the change of primary balance of the government budget as a percentage of GDP between period $t$ and $t-1$.

The expected coefficients are shown in the following Tab. 1.

Table 1: Expected Relations of Independent Variables

\begin{tabular}{|c|c|c|c|}
\hline \multicolumn{2}{|c|}{ Fiscal policy $\Delta\left(\frac{P}{Y}\right)_{t}$} & \multicolumn{2}{|c|}{ Monetary policy $\Delta i_{t}$} \\
\hline Variable & $\begin{array}{c}\text { Expected relation of } \\
\text { parameter }\end{array}$ & Variable & $\begin{array}{c}\text { Expected relation of } \\
\text { parameter }\end{array}$ \\
\hline$\Delta \mathbf{d}_{\mathrm{t}-1}$ & + & $\Delta i_{t}^{G B}$ & + \\
\hline$\underset{P}{E y_{t}}$ & + & $E y_{t}$ & + \\
\hline$\left(\frac{F}{Y}\right)_{t-1}$ & - & $\Delta \pi_{t}$ & + \\
\hline$u_{t}$ & - & $\triangle$ REER & - \\
\hline$\Delta i_{t}$ & $\begin{array}{c}+(\text { coordination }) / \\
-(\text { conflict })\end{array}$ & $\Delta\left(\frac{P}{Y}\right)_{t}$ & $\begin{array}{c}+(\text { coordination }) / \\
-(\text { conflict })\end{array}$ \\
\hline
\end{tabular}

At first, expected coefficients for fiscal policy are mentioned in the Tab 1. Positive relation is expected for the lagged value of the government debt. With increasing total debt, the government should react by reducing deficit to the total government debt will decrease in the following periods. For the positive output gap, when the economy is above potential product, the government should implement a restrictive fiscal policy. For the lagged balance of primary budget as a percentage of GDP, a negative relation is expected, which indicates that the instrument of fiscal policy does not have a complete effect but only partial, and further adaptation occurs in the following period. Expansionary fiscal policy should implement in a situation of increasing rate of unemployment. ${ }^{6}$ The latest variable in the equation of fiscal policy has two scenarios. A positive relation implies coordination of both policies - both in the same direction - carrying out either expansion or restriction. They perform contradictory in the case of the negative relation. One of these policies makes expansion, and the other one restriction.

\footnotetext{
${ }^{6}$ The reaction function for fiscal policy works with an output gap and an unemployment. These variables are not correlated. Despite the fact both variables have quite a similar interpretation, there is no strong multicollinearity because the unemployment reacts later than the output gap. The unemployment is in the reaction function because the low unemployment is one of the most important goals of fiscal policy. Moreover, the reaction of a fiscal balance indicates the extent to which automatic stabilizers work.
} 
In the equation for monetary policy, a positive relation is expected for the change of a ten-year government bond yield. Increasing yield indicates a higher inflation in the future. Monetary policy should react by increasing interest rates. A situation for the output gap is analogous to the situation of fiscal policy. With a positive output gap, when an economy is above its potential output, monetary policy should implement a restriction. Change of the rate of inflation is another variable, for which a positive relation is expected. Monetary policy must respond to the rising rate of inflation by raising interest rates; to decreasing rate of inflation it reacts by reducing interest rates. For the change of real effective exchange rate, a negative relation is expected. With the appreciation, central bank should decrease the interest rate, and the exchange rate should depreciate. Two situations are possible for the last variable which represents fiscal policy. When both policies implement expansion or restriction, there is a positive relation. When both policies are in the conflict, there is a negative relation.

\section{Description of the Data and Methods Used}

The method of the ordinary least squares is used for the equations (1) and (2) mentioned above. A total of eight regression functions were estimated separately, i.e. individually. Each of the equations was examined separately as a single equation model. In the simultaneous equation models (SEM), more than one dependent variable is involved and the model necessitates as many equations as is the number of endogenous variables. The fact that the endogenous variable in one equation may appear as an explanatory variable in other equation of the system is a unique feature of simultaneous equation models. For this reason, such an endogenous explanatory variable becomes stochastic and is usually correlated with the disturbance term of the equation in which it appears as an explanatory variable. In this situation the OLS method may not be applied. One of the crucial assumption of the method of OLS is that the explanatory variables are either nonstochastic or, if stochastic (random), distributed independently of the stochastic disturbance term. If neither of these conditions is met, then the least-squares estimators are not biased but also inconsistent. For this reason we consider a model with independent equations, despite the fact that there is a limited amount of information in estimation procedures for individual reaction functions (Gujarati and Porter, 2009).

Furthermore, statistical and economic verification is made and basic econometric tests (econometric verification) are performed. The data obtained were statistically analysed, extreme values replaced, tests of stationarity of time series conducted using ADF (Augmented Dickey-Fuller test), as well as autocorrelation (ACF) and partial autocorrelation (PACF) tests. ${ }^{7}$ The next step is to determine the extent of dependence of both policies on business cycle, how authorities behave during achieving their aims, how they react to the changing economic environment and, in particular, to what extent and how one policy reacts to that of the other.

\footnotetext{
${ }^{7}$ All variables are stationary (because most of them are differentiated), except the variable rate of unemployment. But rather than its change, the government follows the level of unemployment.
} 
The data are obtained from the Eurostat, the European Central Bank (ECB) and the Organization for Economic Cooperation and Development (OECD), specifically the primary balance ${ }^{8}$ from ECB, the government debt, the interest rate, ${ }^{9}$ GDP, ${ }^{10}$ rate of unemployment, interest rate of ten-year government bond yield from Eurostat and the rate of inflation from OECD. The reference period covers quarterly data from the first quarter of 2000 to the fourth quarter of 2012. The countries of the Visegrad Group (the Czech Republic, Slovakia, Poland and Hungary) are examined. Slovakia is one of the analyzed countries, despite the fact that it has been the euro area member since 2009 . Monetary policy (interest rates) of the ECB is obviously not adjusted exclusively by indicators of Slovak economy. This country is analyzed because the interaction of fiscal and monetary policy can still be examined. We assume that just common monetary policy in the euro area countries will be relatively problematic with the interaction of the fiscal policy in Slovakia.

\section{Results}

The Czech Republic

The model evaluation for the Czech Republic is introduced in the Tab. 2 and Tab. 3.

Table 2: Reaction of Fiscal Policy in the Czech Republic

\begin{tabular}{c|ccc}
\hline \multicolumn{3}{c}{ The dependent variable $\Delta\left(\frac{\boldsymbol{P}}{\boldsymbol{Y}}\right)_{\boldsymbol{t}}$} & \\
\hline $\begin{array}{c}\text { The independent } \\
\text { variable }\end{array}$ & coefficients & t-statistics & $\begin{array}{c}\text { Adjusted R- } \\
\text { square }\end{array}$ \\
$\Delta \mathbf{d}_{\mathbf{t}-\mathbf{1}}$ & $-2.46 \mathrm{E}-06$ & -0.327785 & 59.2180 \\
$\mathbf{E} \mathbf{y}_{\mathbf{t}}$ & $0.226027 *$ & 1.752047 & F-statistic \\
$\left(\frac{\mathbf{P}}{\mathbf{Y}}\right)_{\mathbf{t}-\mathbf{1}}$ & $-1.189016^{*} * *$ & -8.179332 & 15.23020 \\
$\mathbf{u}_{\mathbf{t}}$ & $-0.802233 * * *$ & -3.420721 & Prob (F-statistic) \\
$\Delta \mathbf{i}_{\mathbf{t}}$ & $2.532547 * * *$ & 2.890318 & 0.000000 \\
\hline
\end{tabular}

Note: $* * * 1 \%$ significance level, $* * 5 \%$ significance level, $* 10 \%$ significance level

Source: authors' calculations

\footnotetext{
${ }^{8}$ Primary balance is defined as government net borrowing or net lending, excluding interest payments on consolidated government liabilities; positive values of the variable represent the primary balance surplus and vice versa.

${ }^{9}$ There are Official Refinancing Operation Rates, i.e. for example it is $2 \mathrm{~W}$ Repo Rate in the case of the Czech Republic. In the case of Slovakia, the main interest rate of the ECB is used from 2009.

${ }^{10}$ Variable output gap is estimated from GDP growth rates using the Hodrick-Prescott filter.
} 
As far as the results of the fiscal policy estimated function in the Czech Republic are concerned, the following variables are statistically significant: the output gap $\left(E y_{t}\right)$ at the $10 \%$ significance level, the lagged value of primary balance as a percentage of GDP $\left(\left(\frac{P}{Y}\right)_{t-1}\right)$, the rate of unemployment $\left(u_{t}\right)$ and the change of an interest rate $\left(\Delta i_{t}\right)$. In the case of the output gap and the rate of unemployment, the relations are within expectation. For the output gap, there is a positive relation, which means that fiscal policy performs anti-cycle policy. For the change of unemployment rate there is a negative relation. The government performs expansion during the period of increasing unemployment to decrease it. For the variable $\left(\frac{P}{Y}\right)_{t-1}$, there is the negative relation, which means an inertia adaptation of fiscal policy to the previous period. For variable $\Delta i_{t}$, there is a positive relation, which means that fiscal policy cooperates with monetary policy and adjusts its behaviour. The variable $\Delta d_{t-1}$ is statistically insignificant. The negative relation means that the government does not make efforts to lower the state debt in absolute values.

The results for monetary policy are presented in the Tab. 3 .

Table 3: Reaction of Monetary Policy in the Czech Republic

\begin{tabular}{|c|c|c|c|}
\hline \multicolumn{4}{|c|}{ The dependent variable $\Delta i_{t}$} \\
\hline $\begin{array}{c}\text { The independent } \\
\text { variable }\end{array}$ & coefficients & t-statistics & $\begin{array}{l}\text { Adjusted R- } \\
\text { square }\end{array}$ \\
\hline$\Delta \mathbf{i}_{\mathrm{t}}^{\mathrm{GB}}$ & $0.187633^{* *} *$ & 2.133404 & 0.529780 \\
\hline$E y_{t}$ & $0.031007 *$ & 2.006153 & F-statistic \\
\hline$\Delta \pi_{t}$ & $0.136945^{* * *}$ & 3.370365 & 11.36531 \\
\hline$\triangle R E E R$ & $0.021565^{*}$ & 1.801038 & \\
\hline$\Delta\left(\frac{P}{Y}\right)_{t}$ & 0.019114 & 1.513173 & $\begin{array}{c}\text { Prob (F-statistic) } \\
0.000001\end{array}$ \\
\hline
\end{tabular}

Source: authors' calculations

In the case of a monetary policy reaction function, the change of a ten-year government bond yields, the output gap, the change of inflation rate and the change of real effective exchange rate can be seen as statistically significant variables. The relations for all (except $\triangle R E E R$ ) variables are within what has been expected. During the period under observation, monetary restriction responds by increasing ten-year government bond yields (growing inflation expectations). Monetary restriction is realized in the case of a positive output gap, too. It is similar during the period increasing inflation. A central bank performs restrictions against higher inflation. The variable $\triangle R E E R$ is statistically significance, but in the opposite direction. The variable representing fiscal policy has a positive relation, which would mean that both policies react in the same direction; Wyplosz (1999) describes this fact as a complementary of economic political authorities. 
Nevertheless, this variable is not significant even at a $10 \%$ significance level, which means that monetary policy does not respond to fiscal policy decision-making.

\section{Slovakia}

The model evaluation for Slovakia is introduced in the Tab. 4 and Tab. 5.

Table 4: Reaction of Fiscal Policy in Slovakia

\begin{tabular}{|c|c|c|c|}
\hline \multicolumn{4}{|c|}{ The dependent variable $\Delta\left(\frac{P}{Y}\right)_{t}$} \\
\hline $\begin{array}{c}\text { The independent } \\
\text { variable }\end{array}$ & coefficients & t-statistics & $\begin{array}{l}\text { Adjusted R- } \\
\text { square }\end{array}$ \\
\hline$\Delta \mathbf{d}_{\mathrm{t}-1}$ & $2.50 \mathrm{E}-05$ & 0.072821 & 0.264237 \\
\hline $\mathbf{E y}_{\mathbf{t}}$ & $0.288352 * * *$ & 2.759648 & F-statistic \\
\hline$\stackrel{P}{\left(\frac{P}{r}\right)_{t-1}}$ & $-0.413325 * * *$ & -3.775939 & 4.519513 \\
\hline $\mathbf{u}_{t}$ & 0.037683 & 0.406799 & $\begin{array}{c}\text { Prob (F-statistic) } \\
0.002068\end{array}$ \\
\hline$\Delta \mathbf{i}_{\mathbf{t}}$ & -0.789358 & -0.811344 & \\
\hline
\end{tabular}

Note: $* * * 1 \%$ significance level, $* * 5 \%$ significance level, $* 10 \%$ significance level

Source: authors' calculations

Having estimated the function of the fiscal policy of Slovakia, we can say that the following variables are statistically significant: the output gap $(E y)$ and a lagged rate of primary balance of a state budget as a percentage of GDP $\left(\left(\frac{P}{Y}\right)_{t-1}\right)$. The variable $E y_{t}$ is within our expectation. Fiscal policy performs in an anti-cycle way. For the variable $\left(\frac{P}{Y}\right)_{t-1}$, there is a negative relation, which means inertia adaptation to the previous period. Variables $\Delta d_{t-1}$ and $u_{t}$ are statistically insignificant (at $1 \%, 5 \%$ or $10 \%$ of the significance level). Nevertheless, the relations are within the expectation. The variable $\Delta i_{t}$, representing monetary policy is statistically insignificant. It means that fiscal policy does not respond to the behaviour of monetary policy. The negative relation means inconsistence of both policies; Wyplosz (1999) names this situation as reciprocal substitution of economy authorities instruments.

The results of monetary policy reaction functions are presented in the following Tab. 5 .

For monetary policy, reaction function of the output gap $\left(E y_{t}\right)$ is significant. The positive relation is within the expectation. The inflation is significant at $10 \%$ level. The positive relation is within the expectation, too. Monetary policy responds in an anticycle way. The other variables are not significant even at a $10 \%$ of significance level. Nevertheless, the relations for the variables $\Delta i_{t}^{G B}$ and $\triangle R E E R$ are within what it is expected. There is a negative relation for the variable representing fiscal policy, which implies a conflict of the two policies. 
Table 5: Reaction of Monetary Policy in Slovakia

\begin{tabular}{|c|c|c|c|}
\hline \multicolumn{4}{|c|}{ The dependent variable $\Delta i_{t}$} \\
\hline $\begin{array}{c}\text { The independent } \\
\text { variable }\end{array}$ & coefficients & t-statistics & $\begin{array}{l}\text { Adjusted R- } \\
\text { square }\end{array}$ \\
\hline$\Delta \mathbf{i}_{\mathbf{t}}^{\mathbf{G B}}$ & 0.127634 & 1.106973 & 0.217476 \\
\hline$E y_{t}$ & $0.035434 * *$ & 2.279612 & F-statistic \\
\hline$\Delta \pi_{t}$ & $0.071203^{*}$ & 1.691033 & 3.556824 \\
\hline$\triangle$ REER & -0.036103 & -1.617044 & \\
\hline$\Delta\left(\frac{P}{Y}\right)_{t}$ & -0.001688 & -0.074990 & $\begin{array}{c}\text { Prob (F-statistic) } \\
0.009196\end{array}$ \\
\hline
\end{tabular}

Note: $* * * 1 \%$ significance level, $* * 5 \%$ significance level, $* 10 \%$ significance level

Source: authors' calculations

\section{Poland}

The model evaluation for Poland is introduced in the Tab. 6 and Tab. 7.

Table 6: Reaction of Fiscal Policy in Poland

\begin{tabular}{c|ccc}
\hline \multicolumn{4}{c}{ The dependent variable $\Delta\left(\frac{\boldsymbol{P}}{\boldsymbol{Y}}\right)_{\boldsymbol{t}}$} \\
\hline $\begin{array}{c}\text { The independent } \\
\text { variable }\end{array}$ & coefficients & t-statistics & $\begin{array}{c}\text { Adjusted R- } \\
\text { square }\end{array}$ \\
$\Delta \mathbf{d}_{\mathrm{t}-\mathbf{1}}$ & $-9.09 \mathrm{E}-06$ & -0.435178 & 0.375909 \\
$\boldsymbol{E} \boldsymbol{y}_{\boldsymbol{t}}$ & 0.192618 & 0.862200 & F-statistic \\
$\left(\frac{\boldsymbol{P}}{\boldsymbol{Y}}\right)_{\boldsymbol{t}-\mathbf{1}}$ & $-0.868181 * * *$ & -5.473993 & 6.902842 \\
$\boldsymbol{u}_{\boldsymbol{t}}$ & -0.009198 & -0.151664 & Prob (F-statistic) \\
$\Delta \boldsymbol{i}_{\boldsymbol{t}}$ & 0.205930 & 0.451751 & 0.000078 \\
\hline
\end{tabular}

Note: $* * * 1 \%$ significance level, $* * 5 \%$ significance level, $* 10 \%$ significance level

Source: authors' calculations

Only variable $\left(\frac{P}{Y}\right)_{t-1}$ is significant for the fiscal reaction function. The negative relation means inertia adaptation to the previous period. Other variables are statistically insignificant. The variables $E y_{t}$ and $u_{t}$ are within the expectations. As far as the variable $\Delta d_{t-1}$ is concerned, there is a negative relation, which means that the government does not make any efforts to decrease the state debt in absolute values. In the case of variable representing monetary policy, there is a positive relation, which implies coordination with fiscal policy.

The results of monetary policy reaction functions are presented in the following Tab. 7 . 
Table 7: Reaction of Monetary Policy in Poland

\begin{tabular}{|c|c|c|c|}
\hline \multicolumn{4}{|c|}{ The dependent variable $\Delta i_{t}$} \\
\hline $\begin{array}{c}\text { The independent } \\
\text { variable }\end{array}$ & coefficients & t-statistics & $\begin{array}{l}\text { Adjusted R- } \\
\text { square }\end{array}$ \\
\hline$\Delta i_{t}^{G B}$ & $0.430865 * * *$ & 3.156163 & 0.577933 \\
\hline$E y_{t}$ & $0.164066^{* * *}$ & 2.994747 & F-statistic \\
\hline$\Delta \pi_{t}$ & $0.235741 * *$ & 2.059383 & 14.69291 \\
\hline$\triangle \mathrm{REER}$ & 0.024730 & 1.622838 & \\
\hline$\Delta\left(\frac{P}{Y}\right)_{t}$ & -0.009017 & -0.276682 & $\begin{array}{c}\text { Prob (F-statistic) } \\
0.000000\end{array}$ \\
\hline
\end{tabular}

Note: $* * * 1 \%$ significance level, $* * 5 \%$ significance level, $* 10 \%$ significance level

Source: authors' calculations

All variables except the variable representing fiscal policy are statistically significant in the case of monetary policy reaction function. In the case of the variable $\Delta\left(\frac{P}{Y}\right)_{t}$ the relation is negative. Monetary policy operates in the opposite direction to fiscal policy. In the case of the other variables, there are relations with expectations. Monetary policy reacts to increasing expectation inflation, to the positive output gap, and to the increasing inflation by higher interest rates and vice versa. The variable $\triangle R E E R$ is not a statistically significant.

Hungary

Hungary is the last of the analyzed countries. The results of reaction functions are introduced in the Tab. 8 and Tab. 9.

Table: 8 Reaction of Fiscal Policy in Hungary

\begin{tabular}{c|ccc}
\hline \multicolumn{4}{c}{ The dependent variable $\boldsymbol{\Delta}\left(\frac{\boldsymbol{P}}{\boldsymbol{Y}}\right)_{\boldsymbol{t}}$} \\
\hline $\begin{array}{c}\text { The independent } \\
\text { variable }\end{array}$ & coefficients & t-statistics & $\begin{array}{c}\text { Adjusted R- } \\
\text { square }\end{array}$ \\
$\Delta \mathbf{d}_{\mathrm{t}-\mathbf{1}}$ & $-3.89 \mathrm{E}-07$ & -0.568988 & 0.368239 \\
$\boldsymbol{E} \boldsymbol{y}_{\boldsymbol{t}}$ & -0.195594 & -0.984037 & F-statistic \\
$\left(\frac{\boldsymbol{P}}{\boldsymbol{Y}}\right)_{\boldsymbol{t}-\mathbf{1}}$ & $-0.785778^{* * *}$ & -5.402405 & 6.712187 \\
$\boldsymbol{u}_{\boldsymbol{t}}$ & $0.420338^{* *}$ & 2.114501 & Prob (F-statistic) \\
$\Delta \boldsymbol{i}_{\boldsymbol{t}}$ & $0.749747 *$ & 1.705459 & 0.000100 \\
\hline
\end{tabular}

Note: $* * * 1 \%$ significance level, $* * 5 \%$ significance level, $* 10 \%$ significance level

Source: authors' calculations 
In the case of fiscal policy reaction function, statistically significant variables are as follows: $\left(\frac{P}{Y}\right)_{t-1}, u_{t}$ and $\Delta i_{t}$. The negative relation of variable $\left(\frac{P}{Y}\right)_{t-1}$ means inertia adaptation of fiscal policy to the previous period. The relation for variable $u_{t}$ is not within expectation. Fiscal policy responds by restriction during the period of increased unemployment. The variable representing monetary policy is significant at $10 \%$ significance level. A positive relation means that fiscal policy cooperates with monetary policy and responds to it. The other variables, $\Delta d_{t-1}$ and $E y_{t}$, are statistically insignificant. In addition, the relations are not within our expectation. Hungarian fiscal policy operates in a pro-cyclical way, which means in a destabilizing direction, and does not react to the increasing public debt value.

The results of reaction function of monetary policy in Hungary are introduced in the Tab. 9.

Table 9: Reaction of Monetary Policy in Hungary

\begin{tabular}{|c|c|c|c|}
\hline \multicolumn{4}{|c|}{ The dependent variable $\Delta i_{t}$} \\
\hline $\begin{array}{c}\text { The independent } \\
\text { variable }\end{array}$ & coefficients & t-statistics & $\begin{array}{l}\text { Adjusted R- } \\
\text { square }\end{array}$ \\
\hline$\Delta \boldsymbol{i}_{t}^{G B}$ & $0.755186^{* * * *}$ & 4.642206 & 0.495795 \\
\hline$E y_{t}$ & $0.070124^{*}$ & 1.928595 & F-statistic \\
\hline$\Delta \pi_{t}$ & $0.169997^{*}$ & 1.889505 & 10.83322 \\
\hline$\Delta$ REER & 0.000359 & 0.012419 & \\
\hline$\Delta\left(\frac{P}{Y}\right)_{t}$ & 0.027644 & 1.297094 & $\begin{array}{c}\text { Prob (F-statistic) } \\
0.000001\end{array}$ \\
\hline
\end{tabular}

Note: $* * * 1 \%$ significance level, $* * 5 \%$ significance level, $* 10 \%$ significance level Source: authors' calculations

All the variables are significant with the exception of the variable representing fiscal policy and the variable $\triangle R E E R$. A positive relation of this variable implies coordination of both policies. The relations for the remaining significant variables are within expectation. In the case of increasing inflation, monetary restriction is performed. It is similar when economy is above its potential product. The variable $\triangle R E E R$ is not statistically significant. 


\section{Summary and Conclusion}

Summary results are introduced in the following Tab. 10.

Table 10: Result's Relations of the Independent Variables

\begin{tabular}{|c|c|c|c|c|c|}
\hline $\begin{array}{l}\text { Monetary } \\
\text { policy } \Delta \dot{i}_{t}\end{array}$ & $\mathbf{C Z}$ & SK & PL & HU & $\begin{array}{c}\text { Expected } \\
\text { relation }\end{array}$ \\
\hline$\Delta i_{t}^{G B}$ & $+* *$ & + & $+* * *$ & $+* * *$ & + \\
\hline$E y_{t}$ & $+*$ & $+* *$ & $+* *$ & $+*$ & + \\
\hline$\Delta \pi_{t}$ & $+* * *$ & $+*$ & $+* *$ & $+*$ & + \\
\hline$\Delta$ REER $_{t_{t}}$ & $+*$ & - & + & + & - \\
\hline$\Delta\left(\frac{P}{Y}\right)_{t}$ & + & - & - & + & $+/-$ \\
\hline $\begin{array}{c}\text { Fiscal policy } \\
\Delta\left(\frac{P}{Y}\right)_{t}\end{array}$ & $\mathrm{CZ}$ & SK & PL & HU & $\begin{array}{c}\text { Expected } \\
\text { relation }\end{array}$ \\
\hline$\Delta \mathbf{d}_{\mathrm{t}-1}$ & - & + & - & - & + \\
\hline$E y_{t}$ & $+^{*}$ & $+* * *$ & + & - & + \\
\hline$\left(\frac{P}{Y}\right)_{t-1}$ & $-* * *$ & $-* * *$ & $-* * *$ & $-* * *$ & - \\
\hline$u_{t}$ & $-* * *$ & + & - & $+* *$ & - \\
\hline$\Delta i_{t}$ & $+* * *$ & - & + & $+^{*}$ & $+/-$ \\
\hline
\end{tabular}

Note: $* * * 1 \%$ significance level, $* * 5 \%$ significance level, $* 10 \%$ significance level

Source: authors' calculations

According to the results, we can conclude in the context of the strategic interactions that monetary policy could play a dominant role in the case of the Czech Republic. The results show a statistically significant reaction of fiscal policy to monetary policy and vice versa, however, monetary policy does not react to fiscal policy. In the case of Slovakia, the relations were negative in both cases, which would mean that monetary and fiscal policies are in a reciprocal conflict and both of them do not consider one another. It has not been confirmed by a statistical significance $(1 \%, 5 \%$ or $10 \%$ significance level). As well as in the case of Poland, statistically significant reactions on each other have not been confirmed. None of these policies takes into consideration (in a setting of their economic political instrument) statistically significant reaction to the other one's behaviour. Hungarian results are very similar to those of the Czech Republic. In the model of the reaction function of the fiscal policy, the variable representing the monetary policy was significant. In the case of the reaction function of monetary policy, however, the variable representing fiscal policy was not significant. When considering sequential decision making, we can conclude that Hungarian monetary policy can play a dominant role. 
Furthermore, we can find that, in certain ways, the decision of fiscal and monetary policy does not vary in the analyzed countries. The results of fiscal policy reaction functions indicated that some results are the same in the surveyed countries. Fiscal policy does not respond to the change in government debt in absolute terms. What is more, the reaction of the primary deficit to the increasing level of the public debt is strictly opposite in all analyzed countries (with the exception of Poland). In the Czech Republic, Slovakia and in Poland, the stabilizing reaction of fiscal policy to the output gap was confirmed (that is to the position of economics in the economy cycle). This reaction in the Czech Republic and Slovakia is statistically significant at $10 \%$ or more precisely at $5 \%$ of significance level.

Monetary policy appears to have a stabilizing effect in all of the countries surveyed. The central bank reacts to changes inflation and also to the output gap with a stabilizing effect. Monetary policy also responds to expected inflation (except Slovakia) with a stabilizing effect. The variable $\triangle R E E R_{\mathrm{t}}$ is a statistically significant only in the case of the Czech Republic. This reaction is not within expectation. The stabilizing reaction of the monetary policy to the output gap ${ }^{11}$ is a remarkable finding indeed. Especially in Hungary, this result should mean the substitution of stabilizing function of fiscal policy by monetary policy. Not surprising is the fact that monetary policy reacts similarly to the changes of its main goal - the inflation level. This reaction is significant at $10 \%$ level only in Slovakia. This fact was caused by Slovak participation in ERM II (with regard to Maastricht criteria of convergence) when monetary policy had two goals - a certain inflation level and the maintenance of fixed exchange rate. And there is a fact that from 2009, Slovakia is a member of the Eurozone and it has lost the autonomy instrument of monetary policy. The similar situation is with the variable that represents long-term rates of interest. Monetary policy reacted statistically significantly (with the exception of Slovakia as well) and it reacted in a stabilizing way to the change of interest rate (approximation of expected inflation). Monetary policy in these countries is influenced by long-term inflation expectations.

As mentioned above, we used a model with independent (individual) equations. In forthcoming papers we will consider solving this problem by using a simultaneous equation model (SEM). Some additional information could be provided by this model.

\section{References}

BALBONI, F., BUTI, M., LARCH, M. (2007). ECB vs. Council vs. Commission: Monetary and Fiscal Policy Interactions in the EMU When Cyclical Conditions are Uncertain. European Economy Economic Papers No. 277. 34 pp. ISBN 978-92-7904630-8.

BEETSMA, R. M. W. J., BOVENBERG, L. A. (1998). Monetary Union without Fiscal Policy Coordination May Discipline Policymakers. Journal of International Economics, 1998. 45 (2). Pp. 239-58. DOI:10.1016/S0022-1996(98)00031-2.

\footnotetext{
${ }^{11}$ Likewise Wyplosz (1999) or Clarida, Galí, Gertler (1998).
} 
BUTI, M., ROEGER, W., VELD In’t J. (2001). Monetary and Fiscal Policy Interactions under a Stability Pact. EUI Working paper. 2001(8). European University Institute.

CLARIDA, R., GALÍ, J., GERTLER, M. (1998). Monetary Policy Rules in Practice: Some International Evidence. European Economic Review. 42 (6), pp. 1033-1067.

DEMERTZIS, M., HUGHES HALLET, A., VIEGI, N. (2004). An independent central bank faced with elected governments. European Journal of Political Economy. 20 (4), pp. 907-922. DOI:10.1016/j.ejpoleco.2003.12.004.

DIXIT, A., LAMBERTINI, L. (2003). Interactions of Commitment and Discretion in Monetary and Fiscal Policies. The American Economic Review. 93 (5), pp. 1522-1542. DOI: $10.1257 / 000282803322655428$.

EUROPEAN CENTRAL BANK. (2013). Statistical Data Warehouse. [online] [cit. 2013-06-23] Available from Internet: http://sdw.ecb.europa.eu/browseSelection.do?DATASET=0\&DATASET =1\&sfl2=4\&R EF_AREA=106\&sfl4=4\&GOVNT_ST_SUFFIX=G\&node=9485585.

EUROSTAT. (2013). Statistics Database [online] [cit. 2013-06-28] Available from Internet:

HTTP://EPP.EUROSTAT.EC.EUROPA.EU/PORTAL/PAGE/PORTAL/STATISTICS/SEARCH_DA TABASE.

FRIEDMAN, M. (1948). A Monetary and Fiscal Framework for Economic Stability. The American Economic Review. 38 (3), pp. 245 - 264.

FRIEDMAN, M. (1968). The Role of Monetary Policy. The American Economic Review. 58 (1), pp. 1-17.

GUJARATI, N. G.; PORTER, D. C. (2009). Basics Econometrics. Boston: McGrawHill Education.

LEEPER, E. M. (2010). Monetary Science, Fiscal Alchemy. NBER Working papers, No. 16510.

MANDEL, M., TOMŠÍK, V. (2001). Mix monetární a fiskální politiky v České republice: Empirická verifikace modelu efektivní tržní klasifikace. Politická ekonomie. 49 (2), pp. 163-175.

MELITZ, J. (2000). Some Cross-Country Evidence about Fiscal Policy Behavior and Consequences for EMU. CREST-INSEE, and CEPR.

MUNDELL, R. A. (1962). The APPRopriate Use of MONETARY AND FisCAL PolICY FOR INTERNAL AND EXTERNAL STABILITY. INTERNATIONAL MONETARY FUND STAFF PAPER. 9(1), PP. 70-79.

MUSCATELli, A., TIRELli, P., TRECROCI, C. (2002). Monetary and Fiscal Policy Interactions over the Cycle: Some Empirical Evidence. Business School - Economics, University of Glasgow Working Papers. 2002 (13).

NORDHAUS, W. D. (1994). Policy Games: Coordination and Independence in Monetary and Fiscal Policies. Brookings Papers on Economic Activity. 25 (2), pp. 139-216. 
ONORANTE, L. (2006). Interaction of Fiscal Policies on the Euro Area: How Much Pressure on the ECB? Economics Working Papers from European University Institute, No ECO2006 (9).

Organisation for Economic Co-operation and Development. (2013). OECD StatExtracts [online] [cit. 2013-06-20] Available from Internet: http://stats.oecd.org/Index.aspx?DataSetCode=MEI_PRICES\#.

ŘEŽÁBEK, P. (2011). Měnová politika a její interakce s politikou fiskální. Praha: Karolinum. ISBN 978-80-246-1894-4.

SARGENT, T. J., WALLACE, N. (1981). Some Unpleasant Monetarist Arithmetic.Federal Reserve Bank of Minneapolis Quarterly Review. 5 (3), pp. 1-17.

TINBERGEN, J. (1954). Centralization and Decentralization in Economic Policy. Amsterdam: North Holland Pub. Co.

WYPLOSZ, Ch. (1999). Economic Policy Coordination in EMU: Strategies and Institutions. In: Financial Supervision and Policy Coordination in the EMU. ZEI Policy Paper, 1999 (B11). 